\title{
Augustine - The problem of peace in a violent world
}

\author{
Paul Kelly
}

\section{Chapter 3 from}

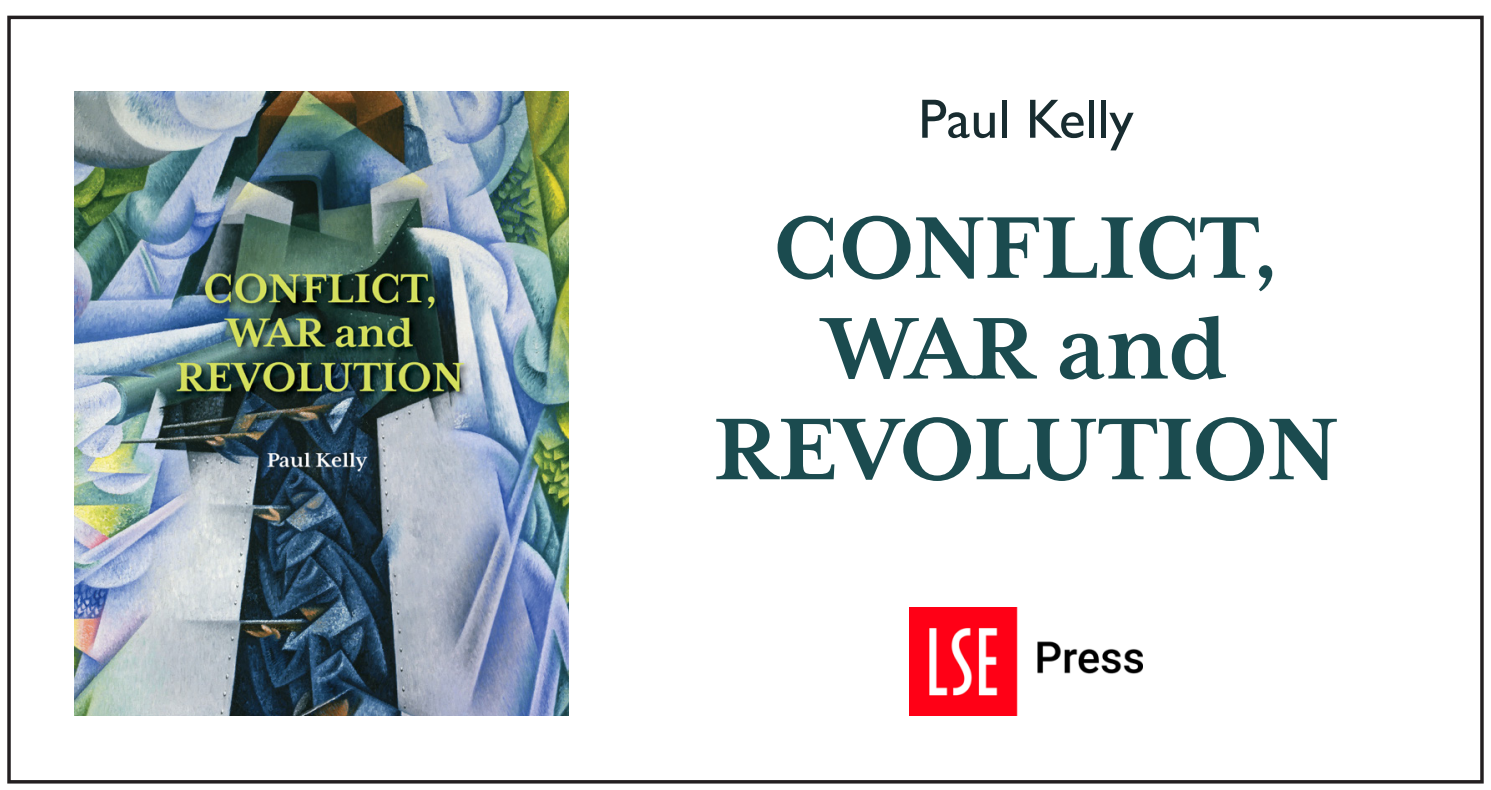

Suggested citation: Kelly, Paul. (2022) '3. Augustine - The problem of peace in a violent world', in Paul Kelly, Conflict, War and Revolution: The problem of politics in international political thought. London: LSE Press, 2022.

https://doi.org/10.31389/lsepress.cwr.c 


\section{CHAPTER 3}

\section{Augustine}

\section{The problem of peace in a violent world}

Augustine is considered to be one of the most important thinkers of the Christian era and an important source of ideas about the nature of politics, war and peace and as a critic of theories of historical progress. I locate his political thinking in an overview of his theology and explore the impact of his understanding of the Christian story of redemption on thinking about the nature, scope and claims of political and moral authority. Augustine's central question is whether the fundamental teachings of Christianity tend towards a utopian and pacificist view of political relationships, or whether the legacy of Christianity in politics and international affairs is more properly understood as a form of realism. Augustine's thought occupies an important place in the development of 'just war' theory and had an impact on the 20th-century resurgence of Christian realism and the anti-utopianism of post-Cold War liberalism.

'Blessed are the peacemakers; for they will be called children of God' (Matthew 5:9).

For Christians, peace is not just relief from war and violence; it is mandated by God as a necessary feature of the order He wills for humanity. In this way, Christianity is pacific in ways that Orthodox Judaism and Islam, or Hinduism and

How to cite this book chapter:

Kelly, Paul. 2022. Conflict, war and revolution: The problem of politics in international political thought. London: LSE Press, pp. 63-104.

DOI: https://doi.org/10.31389//sepress.cwr.c License: CC BY. 
Buddhism (despite the way it is caricatured in the west) are not. Yet, the history of international politics in the west for most of the last two millennia has been one of war and conflict; wars and violence against heretics such as Donatists and Cathars, major international wars against Islam during the Crusades, and the modern international order in Europe emerging from the religious wars that characterised the Reformation and the birth of the modern state. Whether Christianity can be faulted for this history of violence is not the point, but it is undoubtedly the case that professed and committed Christians have been actively involved in the deployment of violence and war, as opposed to living in peace. Christian countries and politicians supported the criminalisation of religious-based conscientious objection during World War I, and came to an awkward accommodation on the issue only in World War II. This paradoxical state is also reflected in the prevalence of avowedly Christian thinkers such as Niebuhr, Butterfield and Wight amongst the critics of interwar idealism and as the founders of modern international relations theory. The place of war alongside peace is a vexed and challenging issue for Christians, most of whom seek to explain and reluctantly accept the violence of the world. For instance, in a country such as the contemporary U.S., which has been involved in war for most of the last 30 years, it has nonetheless been led by Presidents George H.W. Bush, Bill Clinton, George W. Bush, Barack Obama and Joe Biden, who are all avowed Christians. Indeed, President Obama even identified the Christian theologian Reinhold Niebuhr as 'one of my favourite philosophers'. I leave aside former President Trump, but even his administration contained vocal evangelical Christians such as Vice President Pence and former Secretary of State Pompeo, who were both 'hawks' on questions of foreign policy and defence. Yet, alongside Christians taking a realist view, there are also strict Christian pacifists dating from early martyrs, sects such as the Quakers, and contemporary theologians such as Yoder, Hays and Hauerwas (Hauerwas 2002; 2011), who insist that the rejection of violence is central to being Christian.

No Christian thinker captures this seemingly paradoxical situation better than Augustine of Hippo. A Catholic saint and Latin Church father, Augustine is revered throughout the history of Christian theology. He is acknowledged on both sides of the rupture in Christianity that occurred at the birth of modernity with the Reformation: both Luther and Calvin recognised him as an authority, whilst he also continued to be a key figure for the Catholic Counter-Reformation. Although he was not a political philosopher, or a theorist of international relations, Augustine's ideas have shaped the way in which people who have abandoned the fundamental core of Christianity continue to see the world of politics and international affairs. This is similar to the way that those like Niebuhr (who applied Augustine's theological insights directly to 20th-century international affairs) continue to be read by people without religious belief.

No thought can be completely timeless in the sense of being free from the particular context, culture and presuppositions in which it emerges. Yet, one 
challenge of Augustine's Christian thought is that it professes to be based on divine revelation, which claims precisely that universal and transcendent quality. It is the complete and final truth about the nature and purposes of the created order in which humanity resides. As such, Augustine claims to speak to us now in the 21 st century just as he spoke to his contemporaries in the 4 th century of the common era. In consequence, this chapter both explains the main features of Augustine's thought in relation to politics and explores the ways in which his legacy impacts on contemporary thinking about war, violence and history.

\section{Divine order - Jerusalem to Rome}

Augustine's thought has to be set against the backdrop of Christian revelation. As a Catholic Christian, Augustine claims that revelation is not simply the Bible but the lived experience of the Christian Church that followed the death and resurrection of Jesus Christ in the early years of the common era. The Church is important because it is the source of the authoritative witness that is recorded in the books of the Bible. Consequently, distinguishing what is essential to that revelation from other contemporaneous books that are not included in the Bible is a key task. This is particularly important for Christians such as Augustine because the Christian revelation is not simply a new set of laws and commandments akin to the Mosaic Law of the Hebrew Bible (or even the new law of the Koran). The Christian revelation is not simply the words and teaching of Jesus, important though they become. It is the record of his active ministry and then the story of his prosecution, execution by crucifixion and death (which Christians refer to as the Passion), followed by his resurrection from the dead, his eventual bodily ascension into Heaven, and the coming of the holy spirit at Pentecost. In this way the life, death and resurrection of Jesus are the source of the fundamental Christian truth of the Trinity or the threefold nature of God, and it is from this that all other things follow, such as Christian morality and law.

For Christians, revelation is an account of God's presence in the world of history but one in which that history of presence and engagement is ongoing - it will only be completed with the Parousia or 'second coming' of Christ in judgement, this time in triumph, at the end of time. This is the coming of the 'Kingdom', which Jesus claimed is not an earthly kingdom such as that of biblical Israel. Christian revelation radically transforms some familiar political concepts. For the earliest Christians, this apocalyptic culmination of history was expected to be imminent. Indeed, the very earliest Christians probably expected it to occur in their own lifetimes, but it did not happen. Thus, by the time of the writings of St Paul, which are hugely important for Augustine, there is a clear recognition of the challenge of a delayed Parousia and the unfolding 
of human history, a problem that becomes acute with the spread of Christian communities throughout the Roman Empire and their subsequent persecution.

As the Acts of the Apostles illustrates, very early in Christian history the action shifted from Jerusalem to Rome, with both St Peter and St Paul ending their lives there. This spread of the Christian community was accelerated by the sack of Jerusalem by the Romans, but perhaps more importantly by the transition of Christianity from a millenarian Jewish sect into a distinct community, open through conversion to Gentiles, or non-Jews. From its earliest Roman history, the Church was seen as an alien force that challenged traditional public religious cults and therefore suffered periodic and severe persecutions. These began with Emperor Nero's persecution of the Christians following the Great Fire of Rome in 64 ce. Major Empire-wide persecutions were instituted by Emperor Decius in 250 ce, culminating in that of Diocletian in 303 ce. This resulted in the schism of the Donatists, who refused the ecclesiastical domination of bishops who had compromised with the Roman authorities to avoid punishment. However, Christianity spread beyond its initial appeal to the class of slaves, traders and immigrants and continued to permeate all social classes. The Emperor Constantine I converted to Christianity in 312 ce. Christianity became the official religion of the Roman Empire during the reign of Theodosius I (347-395 ce). The conversion of Constantine and the apparent Christianisation of the Empire led some prominent Christian thinkers (such as Eusebius of Caesarea (260-340 ce)) to suggest that millennial prophecies about the triumph of Christ's Kingdom were being realised by a Christian emperor and a Christian empire. It is precisely this simple alignment of imperial history and divine providence (or Constantinianism) that Augustine rejects in his theological and pastoral writings.

\section{Augustine of Hippo}

Writing to a correspondent, Augustine describes himself as 'an African, writing for Africans, both of us living in Africa' (Brown 2000, p. 127). In his role as a Latin father of Christianity and a prolific late Roman author, it is easy and dangerous to forget this important feature of Augustine's biography. In most iconography he is depicted as European, that is, white; he was not. Similarly, although he lived in the Western Empire, Roman Africa was a distinctive and powerful culture in its own right, something that was fully recognised when he went to Rome and then to Milan. Augustine was born in Thagaste (in modern-day Algeria) in 354 ce. His father, Patrick, was a small landholder who made great sacrifices for his son's education, as did the family friend Romanianus, who was also a minor Roman official. Augustine's mother, Monica, who later was made a Catholic saint, was an active and observant Christian. She had a major impact on Augustine's personal and spiritual development, a fact immortalised in his most famous work, the Confessions. Written in 401, this 
work is a model for modern autobiography as it depicts the formation of a mind and character. For Augustine it was the story of his spiritual formation and conversion. It remains the best source of information on Augustine's life, but it needs to be read with care as this is obviously a story with a particular conclusion - the triumph of faith in his life. Augustine's education was in the Latin classics; he never mastered Greek. Nevertheless, his studies progressed sufficiently for him to move to Rome and then to Milan, the imperial capital, where he was Professor of Rhetoric at the age of 31 . His studies and his move to Italy were originally intended as a preparation for entry into the Imperial Civil Service, with the wealth and prestige that would follow. However, his intellectual and ultimately spiritual quest took him in a different direction.

In Milan he fell under the influence of the Bishop Ambrose (another saint) and lost his Manichean 'faith', coming to appreciate the truth of Christian scripture - which he had originally found unpersuasive and vulgar in contrast to Manichean mysticism and Platonist metaphysics. Although Augustine is clear that his conversion is a matter of divine grace, Ambrose certainly assisted in the formation that would lead to the famous conversion experience recounted in the Confessions, where a childlike voice urging him to 'take up and read' resulted in him returning to scripture and the conversion event. After a retreat to Cassiciacum, near Lake Como, Augustine and a group of followers returned to Thagaste in north Africa to establish a form of monastic life: a community devoted to the study and discussion of truth, clearly led by the intellectually dominant Augustine. At the same time, this community was very different from the austere world renunciation of those Egyptian desert fathers who were inspired by St Anthony.

In 395 ce, Augustine was elected as Bishop of Hippo, the second largest port city in Roman north Africa, where he remained until his death in 430 ce. During this period, Augustine wrote on almost every aspect of theology and the pastoral care of his congregation. In so doing, he engaged with the challenges to the Church from within (such as the Donatists and the Pelagians), as well as the temporal challenges from external enemies (such as the Vandals, who threatened the Empire in north Africa in his final years).

\section{Situating 'The City of God'}

The City of God against the Pagans is Augustine's key text. It is an extraordinary work. In modern paperback editions, it is over a thousand pages of closely printed text, yet it was written at a time when the technology of writing, let alone publication and dissemination, was a major challenge. Movable type printing would not appear for a further thousand years. As a comprehensive Christian response to pagan thought, it is extraordinarily wide-ranging and therefore it cannot be reduced to any simple task. It was completed between 413 and 427 ce and closely follows the sack of Rome by the Goths in 410, so it 
is inevitable that the work is seen as a response to this event. The early books offer a polemical response to pagan thinkers and continue Augustine's longstanding defence of Christianity against the pagan learning that he had transcended in becoming Christian. The latter part of the work is more substantial and concentrates on developing a theologically informed account of history. This is often seen as Augustine's direct response to the supposed challenge to Christianity posed by the sack of Rome and the decline of the Western Empire. But it was also a corrective to those earlier Christian thinkers who had seen the conversion of the empire under Theodosius as a sign of a sign of the prophetic triumph of Christ's kingdom.

For the pagans, the sack of Rome allowed a non-Christian aristocratic elite to argue that the betrayal of the popular civic religion of Rome and its traditional practices by Christians had not protected the empire from the "wrath of the gods'. As the traditional religion of the Romans was primarily a series of public cults, the defenders of these traditional 'gods' (hence pagans) did not have to believe in their reality. It would have been enough for these practices to serve as sources of social cohesion rather than ontological justification. The risk for Christians, such as Augustine, was that these critics could raise the question why the Christian God no longer seemed to be guaranteeing His Church and empire. This was unsettling for ordinary Christians, who expected to see the triumph of God's kingdom being revealed in historical events. Scepticism about divine providence was a sufficient challenge, whether or not it was accompanied by actual belief in the gods of traditional Roman religion, and it remained a serious challenge for Christian theologians and apologists in this era.

How does Christian eschatology, or the story of the final destination of humanity, fit with the patterns of historical experience? For early historians of Rome, such as the Greek thinker Polybius (264-146 bce), history has a cyclical structure of the successive 'rise and fall' of the fortunes of political regimes, and history does not have a direction or an end. This stance can be allied with the theories of ideal and corrupt regimes that are found in Plato and Aristotle and which can be used to explain the fortunes of political regimes, in the context of the philosophical knowledge of the ideal form of political experience. The challenge for the Christian is that the resurrection of Christ is supposed to be the culmination or end of human experience and therefore the purpose of history. Yet, history as the succession of events has not ended, nor did it appear to represent the triumph of Christ's church on earth when the institutional life of the Church was threatened and destroyed by barbarian invaders. For Christians, history cannot be the endless repetition of cycles of rising and falling powers or civilisations, and it cannot be the meaningless succession of events, because everything has a purpose in the divinely created order. But how do we discern that order in history and prevent simplistic identifications of historical events with God's providence? This is the fundamental challenge that Augustine sets out to address in The City of God against the Pagans, and in doing so he also develops his mature political theory. 


\section{Political theology versus political philosophy - Augustine's method}

Augustine's thought represents a challenge. Although often included as a major figure in histories of political philosophy or political theory, a cursory acquaintance with his writings illustrates that these categories are an awkward fit for his thought. Augustine writes as a late Roman Christian convert who becomes a Catholic Christian bishop. Many writings are not simply on theological topics such as the nature of the Trinity or the soul and creation but rather address the pastoral care of a community besieged by schismatic Donatists and Pelagian heretics. They are also often more mundanely about ecclesiastical politics. Yet, at the heart of Augustine's thought is the centrality of Christian revelation and it is this that raises the most fundamental questions about his method and thought. In an important respect he is undoubtedly a philosopher. His early and formative works and the Confessions exhibit a philosophical engagement with the Platonist philosophy, from Plotinus via Porphyry, that places Augustine within any account of late Roman philosophy. But in another crucial respect he is not a philosopher and would have rejected that description.

The nature of philosophy is a perennial problem for philosophers from Socrates to the present. Philosophy is defined as a love of truth, but in practice it takes two main forms that we find in Plato. In the character of Socrates, we see philosophy as a quest or method of inquiry and in the early Platonic dialogues he interrogates experts to find out what, if anything, they know. Most of these dialogues reduce the claims of experts to a muddle of contradictions, such that real knowledge is reduced to Socrates' famous scepticism: 'he can only be truly certain of what he does not know. This form of critical enquiry leads to scepticism about grand claims and fits our contemporary mode of philosophy as a method of critical analysis, rather than a science or body of doctrines. But Plato also presents us with a conception of philosophy as a body of knowledge through its access to the fundamental truths about the nature of world, revealed through rational enquiry. It is this legacy of Plato that leads to Roman Platonism and which influences Augustine and inspires his rejection of the more sceptical model of philosophy that can be seen in Cicero. However, his philosophy engages him with Christian revelation that provides a final and complete vindication of what Platonism can only intimate. For Augustine there can be no question of what if any truth can we know. We have the gift of the complete and final truth in Christian revelation and in its scriptures, which Augustine regards as a substantial replacement of the literature of pagan classical civilisation. Consequently, philosophy or any other humanistic science can only be a tool for the explication and dissemination of Christian truth. Where philosophy seems to challenge or contradict revelation, it is philosophy that is defective and in error. For Augustine, theology is not one more science to fit into the academic curriculum but the master science of truth that subsumes philosophy as one particular tool. For this reason, it is more appropriate to see Augustine's political thought as a political theology as opposed to a political 
philosophy. This is a model for a form of thinking about politics that continues to be distinctive from the Socratic ideal of philosophy that has dominated western thought since the European Enlightenment.

Augustine's legacy is still alive amongst contemporary political theologians. They claim that the relationship between theology and politics:

is not a question of adapting to alien requirements or submitting to external agenda, but of letting theology be true to its task and freeing it from a forced and unnatural detachment. Political theology tries to recover for faith in God, Christ and Salvation, what scepticism surrendered to mechanistic necessity. (O’Donovan 1996, p. 3)

As we have seen, Christian revelation about the Kingdom of God is not a simple statement of law such that the task of political theology is fundamentally interpretive. It is not just ransacking scripture for theological images of politics, or for apparent statements of what Christ has commanded. Instead, it is a search for an understanding of political experience that is informed by fundamental Christian concepts and which weaves together as a single narrative the history of salvation and the history of human political experience. It would be a grave misunderstanding to seek secularised conceptions of politics in Augustine's theology. We should not look at his views of the Church or Christian community as an intimation of a modern conception of the state or the medieval Christian Empire. Although Augustine does have important things to say about the nature of political community, political agency and the extent of political power, this is from the perspective of fundamental theology and its account of the nature and purpose of human existence. Augustine's political theology is the vehicle through which philosophical history is conducted until the early modern period. His thought continues to affect the shape of that form of enquiry, even in contemporary thought, and even by those who may have abandoned the fundamental Christian beliefs behind his account of the meaning and structure of history. It is for this reason that he remains of interest to contemporary international thinkers, as well as to Christian theologians.

\section{Manicheans, Donatists and Pelagians}

Alongside his political theology, Augustine was also a significant controversialist at a time when Christianity was defining its fundamental doctrines. His status as a Latin father of the Church is an acknowledgement of his important role in this process. He is most famous for his engagement with three rival positions, one (Manichean beliefs) an alternative theology to Christianity that had shaped his early pre-Christian thinking. The other two were movements within the Christian community that threatened its distinctive order and truth, namely Donatism and Pelagianism. Because each of these beliefs provides a 
context for Augustine's own theological and political position, a brief overview of all of them will be useful. They are certainly no longer familiar currency within the history of thought, even amongst very well read Christians. In addition, the three approaches also provide models of political thinking that continue to reappear within our secularised political discourse, because much western political discourse is informed by the theological context from which it emerged.

Manichaeism had its origins in the writings of the 3rd century ce Persian mystic Mani, and was influenced by Jewish and Gnostic (Jewish and early Christian unorthodox ideas that were left behind by the subsequent development of the two traditions) ideas that permeated the late Roman and early Christian period. At its height, the influence of Manicheanism spread across the Roman Empire, through the Middle East and Central Asia, even reaching Song Dynasty China. It was also the spiritual philosophy that Augustine subscribed to as a young man in Italy when straying from his initially superficial Christian upbringing. Because Manichaeism was defeated in its struggle with Christianity and subsequently Islam in the Middle East and Central Asia, we have little direct evidence for its fundamental teachings except through the accounts given by its opponents such as Augustine. Even the history of ideas tends to be written by the victors!

The attraction of Manichaeism for Augustine was its dualistic cosmology that explained the possibility of evil alongside the idea of a soul that is eternal and shares an element of the divine. For Mani, the world is divided between two opposing forces: that of light, which encompasses the realm of truth and the soul, and a world of darkness embodied in the materiality of the body, with its earthly lust and urges. These two forces are in a constant struggle for dominance, and this contest is also part of the human psyche, with a similar conflict between the soul and the material body. So sin and evil are not part of the divine creation of the God of light but the result of the lesser god or demiurge that clashes with light. One consequence of this view, which was comforting (for a time) to Augustine, is that it explains the possibility of evil in the world. Problematically, however, it also frees the individual from responsibility for their compulsive evil actions, such as the tyranny of lust and the desires of the body. Once Augustine had come to abandon this early commitment under the influence of Ambrose of Milan, and had achieved a deeper appreciation of Christian scripture, he devoted much effort to attacking the metaphysics and cosmology of Manichaeism, because of Gnostic efforts to elide Manichean doctrines with Christianity. Although it was a separate religion or philosophy, and therefore not strictly a Christian heresy - that is, a false doctrine that emerges within the Church or Christian community - Manichaeism's perpetual struggle between light and dark or good and evil clearly denies fundamental Catholic doctrines concerning creation, sin, the finality of salvation and the nature of an all-powerful God. Although Augustine's anti-Manichaeism is central to his 
fundamental theology, it does have implications for his political theology and history, not least in Augustine's 'realism'.

Donatism. If Manichaeism is a heresy, Donatism is a schism, that is, a division occurring within the life and structure of the Church or Christian community. Clearly, such divisions have some doctrinal element, but it is their political and physical separation from and challenge to Church authority that are most important. Donatism preoccupied Augustine throughout his priestly and episcopal ministry because it was a largely African phenomenon. The Donatists were a group who separated from the main body of the Church (although in parts of Augustine's Africa they were the majority of Christians) following the final great persecution of Christians in the late Roman Empire. At this time, the Roman authorities in Africa had accepted the handing over and destruction of Christian texts as a compromise for the Christian bishops to avoid further punishment. The Donatists took a stand against the bishops and clergy who compromised in this way and rejected their authority when the persecution ended and these individuals returned to ecclesiastical office. The Donatists were ecclesiastical purists who would not compromise with the world, even when that was the result of an attempt to protect their communities and not merely the acts of weak individuals saving themselves. They could not accept compromise and denied not just the legitimacy of bishops who had compromised with the Roman authorities but that of all clergy who traced their ordination and authority back through those bishops.

Of particular interest amongst the Donatists' beliefs was the way that they saw the physical manifestation of authority in holy texts or 'holy water' used in liturgy. To non-Christian and modern ears, these claims seem hard to credit, but for the Donatists they were the basis for the armed rejection of non-Donatist authority (they, of course, denied that this was legitimate Catholic authority). The Donatists had their own militants, the Circumcellions, whom we would characterise as terrorists. They carried out attacks on persons and property in defence of their claims against Catholics such as Augustine, who narrowly avoided an ambush and death at their hands. As with modern religiously inspired terrorism, the Donatists' purism did not just mean their separation; it also denied the faith of, and declared enmity with, the ordinary Catholic community who were caught up in the struggle. Augustine's primary theological dispute with the Donatists concerned the possibility of a self-identifying pure Church within a corrupt human Church and the purist presumption that goes with it. He was also concerned with the dangers of religiously inspired violence and its tendency to be even more uncompromising than the disinterested brutality of imperial rule. Violence was a part of man's fallen nature and a central feature of Roman imperial rule, but the challenge of the Donatists and the need for Church discipline also drew Augustine into confronting the problem of violence and coercion in the Church and amongst those who claimed to be followers of Jesus. 
Pelagianism. This was another heresy that dominated the later years of Augustine's career. Like Manichaeism, it was also rooted in the problem of the possibility of evil within a divinely created order. This heresy actually continued to resonate into the Reformation and in secularised form into modern political ideologies. It was first condemned by the Council of Carthage (418) following a campaign by Augustine. The belief's originator, Pelagius, was a British theologian who was influential in Rome and advocated an ascetic lifestyle at a time when monastic and personal asceticism was developing as a reaction to the public association of the Church with the Roman imperial order. However, the fundamental issue between Pelagius and orthodox Catholicism, represented by Augustine, concerned the doctrine of original sin. This was the very problem that had encouraged Augustine to flirt with Manichaeism as a young man, namely: how could a good and just God create a world marred by the existence of sin and evil (what subsequent theologians have defined as theodicy)? In contrast to Manicheans, Pelagius did not have recourse to a dualist cosmology and instead located the problem of sin in human free will and culpability. But this raised the problem of heredity in Augustine's interpretation of the Genesis story in the Garden of Eden, when Adam and Eve rejected God through disobedience in eating from the 'tree of knowledge'. The issue here is how could the act of the first humans condemn all mankind through all time with the stain of an 'original sin' that culminates in eternal damnation? The problem is theological and not historical (because for both Augustine and Pelagius the Genesis story is a theological narrative as opposed to a simple natural history). The issue here goes to the heart of God's nature and the place of justice in His creation. For Pelagius, the challenge of double predestination (the idea that God creates some people to be damned for eternity) threatened the idea of the goodness of God's nature and thus His purpose in creating the world. How could a good God predestine some people to damnation from the very earliest moments of creation? Surely this undermines the very idea of human agency, morality and the significance of our actions. In his account of salvation, Pelagius asserts the importance of personal goodness and righteous action. Through good works and personal piety one could merit salvation, and, equally, those souls who are damned must in some way deserve that.

For Augustine, the problem of salvation by good works threatened the essential gift of salvation through Christ's passion, and suggested that salvation could be a personal transaction between humanity and God. This issue of the place of 'works' versus 'grace' was at the heart of Luther's dispute with Rome at the commencement of the Reformation, and it has wider ramifications for western culture in terms of the issue of agency and personal responsibility. If wickedness or evil is not in some way inherent in all of us, then is it not possible that the corruption of our natures is actually the result of external circumstances such as lack of appropriate socialisation or education, or the result of poverty (the problem of moral luck)? If so, then would not a social order that corrected for 
these things be the key to achieving a peaceful and just social order, so that we could actually build a version of Heaven on earth? Augustine's response to each of these challenges shapes his considerable contribution to the subsequent history of Christianity. In addition, as each one casts its own shadow over modern politics through dualism and political and personal perfectionism, so equally Augustine's responses also still cast a similar shadow over contemporary political thought, amongst Christian and non-Christian thinkers alike.

\section{Sin and evil}

The problem of sin and evil is the central thread of all of Augustine's writings and his pastoral or political writings are simply extensions of this fundamental discussion. The challenge and response to sin and evil is central to the drama of each human life or soul (to follow Augustine's Christian and Platonist way of thinking), and it concerns the meaning of each person's life and their ultimate destiny. Augustine's own story is partly captured, beautifully, in his most famous work, the Confessions. In addressing the ultimate destiny of human beings and their relationship with their creator, Augustine is drawn into fundamental theological reflections on the problem of evil and the nature of sin. Indeed, one can read the argument of the Confessions as the conclusion to Augustine's intellectual struggle with the problem of evil or sin in a world created by a good God. The journey is one within a universe that is created and ordered by some divine power: atheism of the modern variety never appears on Augustine's intellectual horizon. Instead, the movement is through a series of philosophical religions (such as Manichaeism or Platonism) to reach the revealed religion of Christianity, which gives a psychological and personal reality to what only existed abstractly in the philosophy of Platonism. Yet the recognition of the universal prevalence of sin or evil in the world of human experience is also central to Augustine's vision of politics and of social life in human history. This is what makes his thought central to Christians seeking to make sense of a created order that is clearly marred by pain, suffering, violence and disorder. But it is also relevant for non-Christian readers who recognise the depiction of human experience as essentially tragic because of violence, war and error, even if they reject Augustine's ultimate explanation of that fact in his account of sin and the fall of humanity.

The problem of evil is relatively simple to state. Given that the world is the product of a creator and that creator is good, how is it that sin, evil or bad are possible? For Platonists, following Plato's metaphysics, the universe is a hierarchically ordered creation at the pinnacle of which is the sovereignty of the good. This structure is a complete rational order, so for Platonists the problem is identifying the rational point of suffering, pain and violence? For Christians, the story is simpler but more challenging. The Genesis story of creation recounts how God created all things. This story takes place over a series of days 
in which different elements of the world are created and acknowledged as good by God: He sees his creation and considers it good. As the source of all created things, God therefore must be responsible for the creation of evil, bad or sin. But, if God created a power of sin or evil, then either He is not good, which for Christians is either a blasphemous or a terrifying idea, or He was negligent in the creation process and therefore not omnipotent, that is, all-powerful and all-seeing. God cannot be weak and He cannot be wrong; to think otherwise is to conceive of God as being less than perfect. Possibly God created evil as a check on humanity of some sort, but again this leaves the idea of God as some kind of cosmic force playing an unnecessary game with His creation. Surely an all-powerful and good God could have created a world without the suffering and pain of cancer and drought, or without the human sources of pain from predators, tyrants, bullies and murderers.

The facts of experience challenge both the philosophers and the Christians with the problem of evil. Responses to that include the Manichaeism explained earlier. This cosmology posits a dual power in the universe in antagonism, namely a force of good or light, and a force of darkness, which are in perpetual struggle. The powers of light are associated in the human psyche with reason and the quest for truth, whereas the powers of darkness are associated with materialism and the body. Humans' psychic or spiritual life is a mirror of the larger cosmic struggle between light and darkness or the spirit and the soul. This dualistic psychology is a recognisable feature of many religions and for some Christians it also provided a way of making sense of some features of their religion such as the place of Satan or the Devil. He appears in the Genesis story as an evil personality and power complicit in the temptation of Adam and Eve and, again, in the temptation of Jesus in his wilderness period, prior to his active ministry, as recorded in the Gospels. There do indeed seem to be two powers at work here. How can Jesus, one of the three persons of the Trinitarian God, be tempted by a 'power' that must in some respects be part of His own creation? We will leave aside the idea of non-human spiritual beings (such as angels, devils and daemons), which were widely shared beliefs throughout the classical and early modern period and central to Christian thinking. The important issue for us is not whether such beings exist - Augustine shared the traditional view of his age, and subsequently of Christianity, that the created order included beings who are not material or bodily.

In Manichaeism there is incessant struggle between these two opposing forces, and the forces of darkness may crowd out the light, like a storm cloud obscuring the sun. As a 'religion', Manichaeism teaches that man can overcome this darkening effect of our material bodies by renouncing things of the flesh, and by abstaining from sex and certain types of food. Many features of Manichean dualism persist into the modern world. Practices of renunciation to achieve enlightenment are common both in contemporary religions and in many 'New Age' philosophies of life. The Manichean dualism also appealed to Augustine because it resonated with his own struggle between the things of 
the body and the intellect or mind. Some argue that traces of this body-mind dualism persist into Augustine's Christianity and its legacy for western thinking, particularly in relation to traditional Christian teaching on sex (Connolly 1993). However, the Manichean cosmology was unstable, as it presented a good God as ultimately weak and vulnerable, because of His unwillingness to use power to destroy the forces of darkness. Manicheans thus purchase cosmological coherence only at the expense of divine perfection.

Augustine achieves his liberation from Manichean dualism with the help of Platonist metaphysics, specifically the doctrine of substances. This allows him to realise that evil is not a thing in the world that exists of its own right and which can be seen as a rival force within a created order, or something whose existence needs explanation. Augustine's breakthrough was achieved by denying that evil is a thing or substance at all. Sin and evil are nothing not a thing. But, in denying that there is such a thing as sin or evil, Augustine is making an ontological claim (that is, a philosophical point about what there is the universe), not an ethical or moral claim. Humans still suffer the experience of sin, evil, harm, pain and violence. However, we should understand these as absences or departures from the good and not substances in the world. In this way, the created order is ultimately good but its goodness is obscured by the absence of the complete goodness of that order in the world of human experience. This is a matter of degree, depending on the enormity of evil. Major evils such as genocide potentially obscure goodness completely, in that they may cause people to deny that the universe can contain, or be, good at all. Small sins or bads may not totally obscure the good, but cumulatively they crowd out goodness in the experience of an individual life. All departures from the good matter: we can illustrate this complex idea in simple terms if we think of injustice not as a separate force in the cosmos but as a lack of or absence of justice. Similarly, pain is an absence of pleasure, order or wholeness in terms of health and well-being. Augustine thinks we can account for all of the perceived evils in human experience in terms of this idea of departures from goodness. This philosophical reorientation certainly provides a way around Manichean dualism and the idea of divided and conflictual cosmos. Yet, Augustine still needs to explain how, if sin and evil are ultimately nothing (Evans 1990, p. 2), they are still such a huge feature of human experience. Augustine's answer to this question is the second important element of the Genesis story, namely its account of the 'Fall of Man'.

The story of 'the Fall', or how Adam and Eve turn their backs on God by disobeying his command to refrain from eating of the tree of knowledge, is a parable about how humanity is created by God with the capacity to know and to love Him as the source of good, but through the exercise of their free will they rebel against or disobey God. The source of sin is rooted in this fundamental act of disobedience. What is significant in this story is that sin or evil has its source in the exercise of human will against the good, as opposed to 
the specific act done. Of course, doing what God prohibited makes that act wrong, but it is the wilfulness of the act that signifies the sin or evil. Consequently, for Augustine the source of evil is not a power in the world acting on humanity but one that originates in the human will with its tendency to reject the truth or the good. Individual acts of wilfulness are the sources of particular evils or wrongs. But the fundamental and universal tendency for the will to overcome reason and the good is the primary source of evil or bad in the universe: it is not a part of the created order but a consequence of how part of that created order - humanity, and only humanity - acts against its creator. By locating the source of evil or wrong in the will, Augustine distinguishes it from mind or reason, where humanity is most close to its creator, and in so doing follows in part the Manichean hostility to the flesh or body. He rejects the materiality of human nature over which will is sovereign in a way that mind or reason is not, and shares the Platonic elevation of mind over spirit and desire, which are rooted in the body. This is also why Augustine has such a negative view of sexuality and especially its manifestation in lust, to the discomfort of modern readers since Freud. The problem of lust, for Augustine, is a paradigm example of the body and will crowding out reason and control. Lust is also a source of tyranny and control over others, who are forced to submit their bodies to domination, power and the will of the powerful. Sex is not just a means of procreation and even enjoyment or an expression of love; it is often a source of domination, control and destruction. Rape and sexual violence are constant features of war and explicitly gross acts of symbolic and actual violence.

The story of the Fall, for Augustine, is the origin of original sin, which is hereditary such that all humanity as the heirs of Adam and Eve share that taint. No one is born free from sin, and in the Confessions Augustine famously describes how this is exhibited in the behaviour and character of human infants or his own childish sinning (such as stealing fruit for the thrill of transgression). It is important to note that the capacity to sin and the wilfulness of our nature have been fundamental since the Fall - they are not things that we acquire in a social context, nor are they learned behaviour. All human beings are sinners, albeit that some are greater sinners than others. Throughout the account of original sin and its transmission through procreation, Augustine is still primarily concerned with the story of each individual soul or psyche and its relation with its creator. At the same time, this story has implications for society and history. The consequences of sin shape human history and account for its structure: history is the story of humanity since the Fall confronting the legacy of original sin and the consequences of individual sinning. This account of the tyranny of individual will shaping the disorder of history and political experience has proved attractive to realist thinkers into the present, even if they deny the biblical story of its origin, because it reflects the limitations of reason and our ability to accept rational direction in politics. 
While the Genesis story explains the origin of sin in the world, its introduction is not the whole story for Christians like Augustine. Sin and evil are the tyranny that human beings create for ourselves by rebelling against God. But God does not give up on humanity. In the person of Jesus, God seeks to redeem us by becoming human in the incarnation so as to take on human sin in the passion and be crucified before rising again and ascending to Heaven. For Augustine, this redemption is by far the most important part of the story of humanity's relation with God because it involves God reaching out to His creation, and potentially to each person, to offer ultimate reconciliation between the created and its creator. This reaching out is the gift of grace, which Christians see as the consequence of Jesus' acting in our world and the bridge between that world and an eternal life freed from sin. The gift of grace is an opportunity to reconcile with God and for us to seek forgiveness for that fundamental wilfulness or rejection of God. The rejection of God is the embracing of sin or evil and being subject to divine punishment - the choice between Heaven and Hell. The source of grace is Christ, but the signs of that gift of redemption are not things that we can simply infer from behaviour and actions. As a gift, it is freely given but it cannot be earned or merited.

This doctrine is what gives rise to Augustine's extensive debates with the followers of Pelagius, who look at good acts and virtuous lives as meriting grace. Put simply and crudely, if good works are not a sign of the grace that is linked to good works or moral behaviour, then why be good, because it will not guarantee redemption? Similarly, if those who have died outside the Church before they could be baptised (such as infants) will be damned, does this not make God cruel and fickle? Finally, if grace cannot be freely sought through works and individual acts, then we confront the problem of double predestination that was to plague Augustine's theological writings in his final years, and which was to become so important to Protestant reformers such as Luther and Calvin. This is the idea that, because an omniscient and omnipotent (all-seeing and allpowerful) God knows and sees the destination of all creation from the initial moment of creation, He must be creating some men to be irredeemable sinners and therefore condemned to damnation. Would it not have been more perfect to have only created those who can be saved? Are we not back with the problem of sin from which we began: how can a good God create an order in which some are damned from the moment of creation whatever they do?

The problem of grace and the mystery of predestination is one of the significant legacies of Augustine to subsequent theology. However, there is one last part of God's revelation of Himself in history as a means of redeeming creation, and that is that the full redemption of humanity is not completed at the point of Christ's resurrection in historical time. (Christians believe that the passion narrative of the Gospels describes actual events that occurred sometime in the fourth decade of what we now describe as the common era (ce).) For Augustine and the Church, God's work of redemption is only completed with His 
promise of the second coming, where Jesus will end human history with the final judgement between the damned and the saved and the establishment of His new Kingdom. Whilst Augustine is clear that this too will be an historical event ending the secular order, or the time of passing away, he is equally clear that it is ultimately a theological matter that ends time as we know and experience it. This has the important consequence that Augustine is not prepared to identify signs of the end of time with signs that occur within historical time. It is for this reason that he is opposed the Constantinians, who saw the end of time with the unification of the Church and the Roman Empire following the conversion of the Empire under Theodosius. Like St Paul in the Epistle to the Thessalonians, he cautions believers against being deceived by those who offer themselves as signs of the second coming, or those who claim that they can accelerate the coming of the Kingdom. Instead, for Augustine, the followers of Christ are condemned to be pilgrims on a journey to that new Kingdom through the world where sin and its powers continue to hold sway. The fate of the Roman Empire at the hands of its own internal destructive forces, or the barbarians invading from beyond its borders, are just another set of obstacles on that journey, and not a sign of some acceleration towards the end times. History remains, for Christians, the time of faith and not the new Kingdom.

All that Augustine teaches about redemption is fundamentally theological and has a reality outside of the world of bodily experience that is subject to time and change. So it leaves the problem of historical experience open. Humanity awaits the coming of the final judgement, yet, because God is outside of time and change, and is therefore in an eternal present, He is not waiting for anything to happen or to unfold in the divine realm. The time of change is a problem only of human experience, and it remains an important problem for Christians. They must confront the historical challenges of pain and change whilst holding to their faith in the resurrection. These problems are particularly current and acutely present for Augustine and his contemporaries, with the threats and challenges to the peace of the Empire and the persistent wilfulness of humans. Even within the Church there are those, such as the Donatist schismatics or Pelagians, who confuse fellow Christians by disseminating different and conflicting accounts of how one must live in this time of change and overcoming - what Augustine refers to as the secular world or Saeculum.

Augustine's fundamental theological writings are intended to reorient humanity away from the trappings of sin and the consequences of evil, by showing that evil is not actually a thing, or a power, but is merely the consequence of humanity's corrupted will. This will is potentially redeemed by the possibility of grace, signified by God becoming present in the world in the person of Jesus Christ. Yet, Augustine never turns away from the world or ignores the challenge of living within that secular order while oriented towards the things of God. In this way, he becomes a political thinker by default rather than intention, by not accepting that Christians have the luxury of turning their 
back on history and experience. What they must not do is confuse the secular order with the unfolding of the individual redemption of their souls. It is this fact that is the key to understanding Augustine's thought about political authority, violence and war. This warning against seeing historical events as a sign of human redemption is also one of Augustine's legacies for contemporary politics, whether viewed from a Christian perspective or not.

\section{The two cities: an Augustinian theory of government and politics}

Augustine's theology of sin and redemption is not a political theory but it has profound implications for his account of the nature of political life and the institutions of government and coercion in the Empire. We might call this his theory of the state - but be mindful of the fact that the state as an entity is an early modern concept that only appears in modern form a millennium after Augustine's death. In the context of the sack of Rome, the theology of sin is important because it disrupts the simple link between theological history or eschatology and the human history of political events. This rupture does not entail that there is no connection between human historical experience and redemption, but it does entail two important lessons. Firstly, as Augustine's response to Pelagianism shows, we cannot infer a simple connection between good actions amongst men and the reward of Heaven, because this would make history itself the vehicle for redemption. Secondly, we cannot infer God's will from perceived patterns in history. To claim that political success measured by human goals (such as the military triumphs of the Roman Empire) is a sign of God's plan unfolding in history is a further example of the pride and sinfulness of human nature. Augustine reminds us that providence might be as well served by political failure as by human flourishing. In neither case is it appropriate for Christians to see a pattern in historical events as a further source of revelation. Theological time and human history are distinct. Augustine is aware that there is a natural and perennial urge for all Christians to seek comfort from patterns in human events, and not simply theologians and philosophers, This remains the fundamental challenge of the secular age as a period of passing away and impermanence, pending the final judgement.

The profound lesson of Augustine's political thought is that politics is appropriate to this secular age and it is not concerned with the fundamental good for man or with human redemption as a Christian variant of the classical goal of politics. Augustine's thought marks a fundamental rupture with natural law as it emerges from the classical sources of Plato, Aristotle and Cicero, and the idea that political action and political life is part of a truly human life. The secular realm is not concerned with achieving the fundamental good for humanity, because that cannot be achieved by human action alone, even when that occurs in a good polity. Instead, the secular realm is one in which the damned 
and the saved continue to live out their human lives, in the shadow of final judgement but before that judgement is given. As such, the secular realm is one characterised by sin and its consequences, and, whilst the Christian (unlike the Manichean) can now be sure that sin cannot ultimately triumph, it remains a constant challenge for Christians as they seek to live out their lives in fidelity to the cross and resurrection of Jesus. Thus, Augustine's political theory should not be seen as an account of the good life for humanity, nor is it about the ideal political community or constitution in which that good can be achieved. Rather, it is essentially a pastoral teaching directed to Christians struggling with the practicalities of living faithfully in a world marked by sin and its signs of violence and coercion: a kind of Christian prudence. This pastoral advice can take the form of specific advice to named individuals, given in letters about how they should act with respect to specific challenges. Alternatively, it can take the form of a larger story or meta-narrative about how Christians should see their position in relation to the received institutions of the Empire and politics - the things of Caesar - and against which they should orient their actions. The most striking example of this is Augustine's distinction between the two cities and the account of political society as 'a gathered multitude ... united by agreeing to share the things they love' (1998, p. 960).

\section{The two cities}

The distinction between the two cities - the city of God and the city of man has become the most familiar feature of Augustine's political thought. It can easily be confused with a distinction of jurisdiction between temporal (political) rule and ecclesiastical authority, especially as the latter was to have such importance in the medieval period. There were intense debates then about the necessary limits of regnum (political jurisdiction, associated with the Holy Roman Emperor) and sacredotium (or ecclesiastical rule, associated with the Pope and bishops), as well as amongst the thinkers of the Reformation. This jurisdictional issue is not Augustine's concern in the distinguishing the two cities, although conflicts of jurisdiction are addressed in exercising episcopal and pastoral authority. Instead, the importance of the two cities is an implication of the reorientation of political thinking from the classical focus on the good life for humanity and the place of politics within it. Augustine is quite clear that the idea of dominion or rule of some human actors over others is not natural; indeed, the natural condition at the time of creation is one of freedom. At creation, humanity is given dominion only over the beasts as irrational creatures: 'He did not intend that His rational creature, made in His own image, should have lordship over any but irrational creatures: not man over man, but man over the beasts' (Augustine 1998, p. 942). Similarly, the first just humans, such as the biblical Abraham, were 'shepherds of flocks, rather than kings of men' (Augustine 1998, p. 942). 
Dominion (or the domination of one human over another) is only a consequence of sin. Political rule is linked with slavery, war and the punishment of sin. Whilst this can seem a deeply pessimistic view of human experience, it is accompanied by Augustine's refocus on sociability, which takes many forms and which is natural, albeit tainted in the fallen world. Human beings have a natural tendency to associate and form societies so as to achieve many different ends - from the most basic of companionship and procreation to more complex collaborative ventures such as education and collective defence, or robbery and murder. Societies are simply 'gathered multitudes' of people agreeing to share and pursue the things that they love. It is in the context of this plurality of forms of social ends that we can locate the distinction between the two cities.

Two cities, then, have been created by two loves: that is, the earthly by love of self, extending even to contempt of God, and the heavenly by love of God extending to contempt for self. The one, therefore, glories in itself, the other in the Lord; the one seeks for glory from men, the other finds its highest glory in God, the Witness of our conscience ... In the Earthly City, princes are as much mastered by the lust for mastery as the nations they subdue are by them; in the Heavenly, all serve one another in charity, rulers by their counsel and subjects by their obedience. (Augustine 1998, p. 632)

I divide the human race into two orders. The one consists of those who live according to man, and the other of those who live according to God's will. Speaking allegorically, I also call these two orders the two Cities: that is, two societies of men, one of which is predestined to reign in eternity with God, and the other of which will undergo eternal punishment with the devil. (Augustine 1998, p. 634)

Augustine's distinction is based on two distinct orientations, and his teaching applies to persons as well as to societies, rather than to institutional structures or territories. And, whilst the plurality of societies and social goals is considerable, the important distinction for Augustine is the type or object of love, and whether those are things of God or of humanity. The objects of love for some social groups will necessarily fall on one side of this distinction. For example, the love of a society of robbers or pirates will necessarily be part of the city of humanity because there could not be a form of righteous or Christian piracy. But some other ends that might be pursued by a society (such as education) could be oriented towards either the city of humanity or the city of God. A straightforward example might be the contrast between a seminary and a business school. Yet even here it is the ultimate orientation and motive of those sharing the goal that really matters, and not the superficial institutional function. A seminary can end up producing students consumed by earthly ambition and pride, whereas the business school can produce those who advance 
the Kingdom of God. It is the kind of love and the orientation of that love that are at the heart of the distinction, and not the constitution, history or nature of rule that distinguishes the two cities. This fact transcends the simple distinction between the Church and the state or political community. Whilst the Church is the gathered body of Christians it remains a visible community of sinners. Some members will simply fall short of their calling, in the way that Reformation thinkers castigated the sins of medieval popes. But, at a more fundamental level, Augustine also sees the conflict between the city of God and the city of humanity operating within the Church in the disputes between Donatist schismatics or heretics, such as Pelagians. In their own way, each of these creeds substitutes the orientation towards love of God with love of humanity, in terms of intellectual pride or a sense of purity and moral superiority over others. Augustine is clear that the idea of the two cities is an allegory, and it is the orientation to love God, versus love of the things of the world, that is the fundamental underpinning of the distinction.

In this way, Augustine introduces an idea of social pluralism in terms of the ends and goals of association in society, whilst rejecting the hierarchy of pluralism amongst the virtues that is derived from Aristotle or more modern ideas of value pluralism. Social pluralism is the fact of human experience and is something to be celebrated and acknowledged. As an educated Roman with an experience of the regional and social differences across the Empire, as well as being aware of the differences of cultures and style of theology between Eastern and Western Christianity, it is unsurprising that Augustine does not privilege a narrow uniformity in human experience. Nevertheless, his core teaching about the value and significance of these social ends, as well as their ordering, is in terms of fundamental orientation. Pagan ways and practices are a denial of the truth, just as the common ends pursued by pirates and brigands are evil.

The contrast between the two cities can lend itself to a distinction between types of political community and political rule. Augustine even uses the orientation of princes towards the things of God and things of the earth as a way of distinguishing good and bad regimes; in the one, the prince is mastered by the lust for 'mastery', and in the other by 'charity'. But, again, the focus is on the character and orientation of the ruler and not the constitution or state as such. This allows Augustine to acknowledge that genuine Christians could, and have been, Roman emperors and steered the Empire towards the things of God, without conceding that the Empire itself was therefore a vehicle of divine providence. No political society in a fallen world can be simply identified with the city of God, because, in a world marked by sin and pending final judgement, the two cities will be constantly intermingled in ways that mere human judgement cannot ultimately untangle. This precludes any form of utopian politics in secular history, whether that is of a classical form of a Platonic or Ciceronian ideal republic, or an ideal and pure church free from sinners. Until the final judgement that separates the damned and the saved, 
human history and human society will always be made up of an intermingling of the two cities.

\section{Justice and the Empire}

Augustine's anti-utopianism (and assertion of the inseparability of the two cities before the time of final judgement) also explains his rather curious denial that the Roman Empire was ever a commonwealth or a genuine republic. In Book XIX, Augustine challenges Cicero's conception of the Republic as a multitude or community of 'friends', that is, a voluntary association unlike a family, united in 'common agreement as to what is right' (Augustine 1998, p. 950). For Cicero, this agreement on 'the right or justice' was primarily concerned with the administration of property and its defence, thus presaging the argument of Locke 18 centuries later. This Ciceronian republican ideal is one with a lasting resonance and is still captured in Rawls's famous statement at the beginning of $A$ Theory of Justice that 'justice is the first virtue of social institutions' (Rawls 1972, p. 3). Augustine rejects this position because it repeats the false idea (inherited from Aristotelian thinking) that political society is natural and entailed by the idea of the human good. Augustine's critique of Ciceronian republicanism is twofold: firstly, he rejects the idea that the human good can be separated from the Christian idea of humanity's ultimate goal and purpose; and, secondly, he rejects Cicero's implication about the moral justification of the Roman Empire as a just republic, in order to challenge pagan criticism of Christianity in the face of the sack of Rome and the barbarian threats facing the Empire.

The fundamental argument against the justice of the Empire, and therefore its claim to be a commonwealth, draws on the place of pagan civic religion in Roman life, either through its early and classical history or in the form of a revived pagan civil religion that Augustine's critics were defending. No social order that demands the worship of false gods, or what Augustine calls 'demons', can be a moral order and thus by definition pre-Empire Rome cannot be a commonwealth. The argument is both a conceptual sleight of hand and a moral critique of the pre-Christian order. It is the former because Augustine denies that there can be a narrowly human or political morality that can be separated from the fundamental theological basis of moral virtues and concepts: he therefore rules out precisely what contemporary political liberals like Rawls (following Cicero) wish to assert, namely that justice is a 'political' value. And it is the latter genuine critique in that it reasserts Augustine's view that we cannot see any historical political community as necessarily good or just. However, we wish to describe what Cicero intended: by using the concept of 'republic' or 'commonwealth', we are not naming a genuine commonwealth because it is another version of the earthly city, rejecting justice by requiring the worship of idols or demons, by which Augustine meant the false gods of folk religion. Only a city 
oriented towards the worship of the true God could possibly be just in the way that Cicero's account of republicanism would require. That would require the Empire to be the city of God. Whilst some Christian thinkers identified the post-Constantinian Empire with providence, Augustine was clear that we cannot identify the Empire or any other existing or historical political society as the city of God, because all actual human cities remain an inseparable mix of the two cities. This point brings us back to the fundamental Augustinian insight about the nature of politics and history, namely that, until the final judgement at the end of time, the historical order is not and should not be seen as the unfolding of humanity's moral redemption or fulfilment. The historical order is the rise and passing away of orders and societies pending the final judgement, and that is ultimately how we must see the fate of the Roman Empire and all political societies: not as a sign of providence.

It would be possible to draw a deeply pessimistic conclusion from this rejection of historical teleology and the triumph of justice, by retreating from the world. Instead, Augustine does provide a qualified account of the 'first virtue' of political society with his doctrine of peace. We cannot shun or retreat from the world despite its sinful character, because that is the order into which we have been placed by God. To that extent, the political societies that are given within that historical order have a place in whatever God's providence turns out to be. In this respect, Augustine goes back to the injunction of Jesus to 'Render unto Caesar, the things that are Caesar's' (Matthew 22:21) and his teaching that his 'Kingdom is not of this world'. From this, Augustine infers that Christians are compelled to acknowledge the claims of political authority and to exercise political judgement, rather than retreat from the world. At the same time, they must not fall victim to the human tendency to conflate the good of political authority with justice and the moral good. Yet, if political authority is not redeemed by the concept of justice or the good, what is the fundamental good of political authority? Augustine answers this question with an account of peace as the first virtue of political society.

\section{Peace and political order}

Having rejected the primacy of justice as the value underpinning the claims of political authority, Augustine replaces it with the more fundamental idea of peace. In the extended discussion of peace in City of God (Book XIX, Chapters 12 and 13), peace is described as a good for humans in the fallen world, as well as being the central and final gift of human redemption. Yet, it is the good for the fallen world that is central to his account of the value of political authority. And, because the human good of peace is likely to be confused with the supreme Christian good of the city of God, Augustine distinguishes the latter as 'eternal peace'. Even those not oriented towards the 'eternal peace' of the city of God can nevertheless be oriented to (human) peace: 
Whoever joins me in an examination, however, cursory, of human affairs and our common nature will acknowledge that, just as there is no one who does not wish to be joyful, so there is not one who does not wish to have peace. (Augustine 1998, p. 934)

Peace is a value that underpins any form of society because it is the condition of order on which any social life depends. As such, it is a condition of the realisation of the good life of the city of God but equally it underpins the city of humanity. Those who pursue war and violence do so ultimately in order to achieve peace, either through the defeat of enemies who threaten their peace or in terms of conquest and aggression in order to impose a new peace from which they will benefit through the exercise of domination and power. Bands of robbers 'wish to have peace with their fellows, if only in order to invade the peace of others with greater force and safety' (Augustine 1998, p. 934). Augustine goes on to argue that, even when bands of robbers turn against themselves, the individual robbers and brigands will still want some peace for their family and children so that they can enjoy the gains of their activities. Whatever the direct motive of contemporary drug lords, gangsters and criminals is, they all presuppose some form of peace that can be ordered to their advantage. And, to pre-empt those who might argue that there are some who are so evil that they just revel in violence and disorder, Augustine introduces the mythical figure of kakos, the half-man:

He gave nothing to anyone; rather, he took what he wanted from anyone he could and whenever he could. Despite, all this, however, in the solitude of his own cave, the floor of which reeked with the blood of recent butchery, he wished for nothing other than the peace in which no one should molest him, and a rest which no man's violence, or the fear of it, should disturb. Also, he desired to be at peace with his own body; and in so far as he had such peace, all was well with him. (Augustine 1998, p. 935)

Peace is the condition of any kind of good, even the most depraved goals of the earthly city. And even those who crave the absence of human society still want the absence of violence from others to pursue their anti-social ends. This desire for peace is the legacy of the loss of the peace of creation prior to the fall of humanity and it remains to be seen whether we are oriented towards the good of the earthly or heavenly cities. Consequently, it is the underpinning of the order in which those conflictual goals are pursued, and it is precisely this which for Augustine is the domain of politics.

The peace of the earthly city is a significant departure from the 'eternal peace' of the heavenly city, but on a scale of absence that ends with total chaos and disorder, or the completeness of sin as the absence of good. As long as it falls short of the complete absence of good, earthly peace retains some measure of 
goodness within the order of the fallen world, because it makes possible attaining some of the goods of the city of God in human history and before the final judgement. The measure of that peace is provided within the fallen world by the political imposition of harm, violence and coercion in order to limit the greater violence, coercion and harm of the conflicting wills and goals of the earthly city and of the city of God when faced by the challenges of sin and violence. The limited good of political order, judgement and power is not then the Ciceronian good of justice, or the Christian good of eternal peace, but it is a subordinate good in that it provides the peace that is a precondition of societal goods, whether those of the earthly city or the city of God. To that end, although political authority is not natural, it is part of the ordained order for fallen humanity. In this way, Augustine builds a theory of obligation to the political orders, kingdoms and empires of the fallen world. Along with all other subjects of the Roman Empire, Christians have a duty to submit to their political rulers, and rulers have a duty to rule wisely by exercising judgement in the use of force and coercion (including violence) to secure peace and order. The duty of submission is not conditional on the wise conduct of the rulers, but it is also not totally unconditional either. Because the task of political rule is securing peace in which the inhabitants of the city of God can pursue their goods alongside the goods of the earthly city, Christians have a duty to submit their judgement to the judgement of that political authority, knowing that ultimately all human judgement is conditional and ultimately subject to divine judgement. In this way, Augustine establishes the traditional Christian response to the challenge of tyrannical rule, namely that subjects should obey the ruler, but ultimately God will be the judge of that ruler.

In some cases where a pagan political ruler claims divine authority, Christians can be faced with the challenge of 'God or Caesar' and the prospect of martyrdom. Yet even here, Augustine is careful not to usurp divine judgement by suggesting that martyrdom is a general duty when faced with the challenges of the fallen world. Whilst celebrating the heroic martyrs of the early Church and their essential witness, his dealings with the Donatists show a realistic appreciation of the demands of Christian witness in a fallen world, and an impatience with Donatist zealots who are too quick to claim divine judgement in counselling martyrdom. Whilst the choice between God and Caesar is clear and unequivocal, Augustine remains profoundly realistic about the complexity of that judgement in ordinary political experience, given the necessity of engaging with the earthly city. As God has deferred the final judgement, it cannot be the right of individual believers to accelerate that judgement in their own circumstances by appealing to martyrdom as the first response to the challenges of the earthly city. Suicide, and willing one's own death, is a sin for Christians. An Augustinian response to the modern-day challenge of suicide bombers seeking martyrdom is clear: they commit the ultimate blasphemy in placing their own judgement over that of God. 
The character of Augustine's political thought is, therefore, neither classically philosophical in its focus on outlining the good life and ideal city or polity nor institutional in the way of contemporary political science. The question of the good life or ideal city is not ultimately a political matter, because it is not something achievable in the fallen world. Politics is an activity peculiar to humanity's fallen nature in the domain of history. Therefore, building ideal states or cities does not arise as the origins of political communities is a product of secular history, and so they are all ultimately temporary and subject to decline. In so far as Augustine contributes to institutional or constitutional politics, it is not in terms of ideal judgements but in terms of the practical manipulation of institutional authority to achieve the end of order: the political task is how we can live together in peace, not how we recreate the world to serve our own view of justice. A number of things follow from this perspective. It assumes the world as it is, and the distribution of political authority and power as it is given in history, and that means the fact of a plurality of political authorities - although the dominant authority is the Roman Empire, given its scope and power. That said, the Empire was clearly being challenged, both from external powers, such as the invading Goths and Vandals, and by internal centrifugal forces separating the Empire between the East and West.

One must remember that the Empire in Augustine's day was not a single sovereign state on modern lines. The sites of political authority within it were diverse, often being divided amongst the armies of various regional individual powers. Constantine came to power in one such struggle within the Roman Empire by drawing on his northern army. In the Empire of Augustine's experience, there was no single monopoly of violence within a single clearly defined territory, to take Max Weber's account of the minimum conditions of political sovereignty. Furthermore, because there was no simple sovereign in Augustine's political world, we cannot make modern assumptions about the nature of international relations there, or about the contrast between the domestic and the international. Whilst important features of international relations such as trade and war do exist in Augustine's political universe, he was forced to follow the Roman practice of addressing the 'international' in terms of the relations between peoples or 'multitudes'. Some of these sets of people will have existed as distinct bodies within the Empire, in the same way that modern empires contained distinct nationalities. Others will have existed beyond the boundaries of the Empire, such as those who come under the idea of jus gentium (the law of nations or people). But, for Augustine, jus gentium is not a sign of an underlying natural law that governs politics; instead, it is a series of conventions that have evolved to enable minimal peaceful cooperation amongst different peoples who are brought into some form of social cooperation such as trade. As conventions, the law of peoples is not really law at all, since for Augustine law in the earthly city must be lex and not just jus. The concept of jus is a primarily moral notion that we can translate as right and which is linked to the concept of justice. But, as we have seen with Augustine's critique of Cicero and 
the Empire as a commonwealth, the law of the Empire, whilst being law, cannot be conflated with justice or right.

Augustine instead emphasises the idea of a clear, promulgated and sanctioned political will as the basis of laws. Laws are ultimately the enforced will of a political authority and they have a claim on the individual will because they are sanctioned reasons through the imposition of punishment. In this respect, law as lex is a political as opposed to a moral notion, because it is the judgements that the wielder of political authority chooses to enforce and sanction. In the absence of a distinct sphere of international relations and a universal political authority, there cannot be a place for an idea of international law going beyond any temporary conventions that develop amongst peoples who are brought into contact with one another, whether through conflict or through cooperation.

Consequently, Augustine develops a political theory as a conception of political judgement about how best to exercise power, violence and coercion in a way that is consistent with the protection of peace and the purpose of maintaining order. As with the pastoral judgements of a bishop, political judgements are always conditional and subject to revision in the circumstances of history, although they are always oriented towards seeking peace and reducing disorder. Final judgements on all things are the sole prerogative of God, and political rulers and philosophers always err when they substitute their judgement for this final judgement. This position does not entail that anything goes for rulers, but it does remind us that human practical wisdom is cumulative, fragmentary and ultimately never complete. The challenge and necessity of judgement (as opposed to certainty and perfect law) is an ineradicable feature of human experience before the final judgement. It is precisely this necessity for judgement that compels Augustine to address one of the greatest challenges to those committed to peace, namely the challenge of war.

\section{The legitimation of violence and just war}

As we have seen, prior to the final judgement the city of God persists within human history and politics, and its attendant concepts of coercion and violence remain part of that. Augustine is careful to avoid claiming that God wills there to be violence and coercion, and instead says that they follow on from man's fallen nature and the domain of the political within human experience. Violence is a consequence of sin and so not something that Augustine celebrates, any more than he celebrates the necessity of punishment. Consequently, one needs to be careful in attributing to Augustine a theory of just war or just punishment within society or the Church, despite the common claim that he is one of the founders of just war theory, and perhaps the first Christian just war theorist. The most important distinction between Augustine and later Christian just war theorists (such as Aquinas or Vitoria) is that his thinking is not located within the broader structure of natural law theory. The domain of politics 
(whether it be domestic, imperial or international) is not governed by a single law of nature, and therefore just war thinking cannot be an implication of that normative order. Instead, war and violence are a consequence of the absence of a normative order and can only be seen as a reaction to our natural imperfection. In fact, Augustine is not the first significant theorist of just war amongst the fathers of the Church, and the idea is more common amongst those thinkers who tended toward the Constantinian identification of the empire with the divine order. Instead, as with his discussion of violence and coercion, Augustine's teaching about war emerges from a pastoral direction of soldiers and a reflection on the challenges to peace from the gathering powers on the edges of the Empire. There is some truth in the argument that Augustine's writings on just war are designed precisely to limit the claims of a more enthusiastic just war discourse in early Christianity (Markus 1983) and that he does not have a formal theory of the justice of war. That said, given the importance of Augustine's thinking to subsequent Christian just war theory, I will characterise his arguments using conceptual distinctions that emerge later in Christian thinking as developments of his insights.

The pastoral dimension to Augustine's teaching on violence and coercion is clear in in his letters that discuss the necessity of persecuting the Donatists. But it should be remembered that in the Roman world there was no monopoly of violence as the exclusive preserve of the state. The administration of violence was shared between courts, the military, the Church and even households. As such, it was a direct concern of Augustine as a bishop, for whom the exercise of coercion was a personal and not merely an academic problem. His initial position is hostile to coercion or violence. He holds a Christian distaste for violence alongside a genuine worry that its exercise unleashes emotions and motivations that are contrary to those of the city of God. Persuasion, patience and example are all preferable to coercion and violence in the forms of torture and corporal punishment.

Yet, this initial attitude gives way in Letter 93 to Vincentius to a more realist and world-weary recognition of the need for coercive methods, especially when faced by the violence and uncompromising character of Donatist opponents. The arguments of the Letter to Vincentius were to become important in the early modern period in debates about religious persecution versus toleration. But it is important to note that Augustine's primary argument is that appropriate corporeal punishment can remove obstacles to rational persuasion and argument. Coercion is ultimately external to persuasion and people cannot be forced to believe; that said, coerced practice and the punishment of attacks on orthodoxy can open many simple people to the possibility of genuine belief, freed from the fear of coercion by Donatist extremists, such as the Circumcellions. As pastoral writings, Augustine's letters are keen to moderate the proportionate use of violence as seen in Letter 133 to Marcellinus, which appeals for leniency in the punishment of a group of Donatist clerics who were accused of murder and violence against orthodox Catholic clergy. Marcellinus is explicitly 
requested to forgo violent and analogous punishment that mirrors the specific violence of the crime:

I have ... learned that most of them have confessed to committing the homicide of the Catholic presbyter Restitutus and the beating of another ... and of ripping out his eye and cutting off his finger. Because of this, I have been overwhelmed with the greatest anxiety that your Excellency might determine that these people should be punished by the laws so severely that their punishment will match their deeds. (Augustine 1994, pp. 245-246)

As the confessions were extracted only with beatings, as opposed to the whole panoply of torture that Augustine describes, Augustine trusted that Marcellinus will use a similarly lenient attitude in the violent punishment, whilst not saying that they should not suffer violence at all. Punishment is feature of the fallen world and a necessary corrective to wrong and harm in society. However, Augustine does not present a theory of punishment and associated violence in terms of modern retributivism or consequentialism, even though considerations of desert and of consequences inevitably form part of his pastoral teaching. His primary concern is not the justification of the practice of violence but the challenge of acting within the practice of punishment on the character of the person who must exercise the inevitable violence of the political order. This aspect is also crucial to his account of just war and the appropriateness of war in the face of apparent Christian pacifism. Unlike other modern theologians and Christian moralists, Augustine does not ask whether war or the violence of war is allowed.

Just as there was no monopoly of violence in the Roman Empire, so the prevalence of war and conflict in defence of the Empire was a familiar feature of Roman life, especially in Africa, where the threat of attack from those beyond the border was frequent and proximate. Not only had Rome been sacked by the Goths, but the Vandals from Spain had crossed into Roman Africa and were attacking Augustine's own community, while raids by desert tribes from beyond the southern border had always been a feature of the African provinces of the Empire. War was a fact of life, and consequently soldiering was a familiar and necessary profession. Just as Augustine rejects the idea of fleeing from the fallen world into a Christian utopia, so the order within which the city of God can persist will need those who secure its peace. This is illustrated in Augustine's pastoral advice to Boniface in Letter 189, where he supports the young soldier in viewing a military profession as consistent with the duty of Christians by referring to Christ's response to the centurion:

Do not think that it is impossible for anyone serving in the military to please God. Among those who did so was the holy David, to whom the Lord gave such great testimony. Among them also were many just men 
of that time. Among them also was the centurion who said to the Lord 'I am not worthy that you should enter under my roof, but only say the word and my servant will be healed; for I, too, am a man under authority and have soldiers under me: I say to one, "Go", and he goes, and to another, "Come" and he comes, and to my servant, "Do this" and he does it.' (Augustine 1994, p. 219)

This passage, which refers to the Gospel of Matthew, shows how Jesus did not admonish the centurion for being a soldier, but rather acknowledged that he too was 'under authority' and therefore part of the order of peace that is willed for human society. Similarly, Jesus did not deny that the military can be part of that order, so Augustine does not deny the place of the military within the legitimate authorities of the domain of the political. The crucial point here is the absence of any blanket rejection of war and violence, or of a specific command from Jesus to the centurion (and therefore all other soldiers) to put down their weapons and 'turn the other cheek' in the face of violence.

With respect to the conduct of war, Augustine argues that the role of the soldier is that of one who is 'under authority', someone who has a delegated power to kill on behalf of the legitimate ruler who exercises this necessary power to secure peace. Being 'under authority' entails that the soldier, when exercising delegated authority, is not ultimately responsible for actions taken, and therefore can be acting justly by obeying orders, even if the cause determined by the ruler turns out not to be justified. The ruler is ultimately responsible for their soldiers' actions and for the just or unjust killing of others. That said, Augustine does not permit everything in the prosecution of war; the soldier might be required to harm or kill those who harm or kill, but should not will evil against enemies. An honourable soldier is someone with a job to do, but not someone who takes pleasure in violence and the conduct of war. Individual soldiers are expected to obey orders, but they are also expected to act honourably even towards their enemies. Thus Augustine writes:

When fidelity is promised it must be kept, even to an enemy against whom war is being waged ... The will should be concerned with peace and necessity with war, so that God might liberate us from necessity and preserve us in peace. Peace is not sought in order to provoke war, but war is waged in order to attain peace. Be a peacemaker, then, even by fighting, so that through your victory you might bring those whom you defeat to the advantages of peace ... Let necessity slay the warring foe, not your will. As violence is returned to one who rebels and resists, so should mercy be to one who has been conquered or captured. (Augustine 1994, p. 220)

As the goal of war is to protect or restore peace, once peace is achieved, conduct towards enemies should also be directed towards peace, and those who are 
conquered should not be executed or enslaved. Similarly, the ends of war are limited towards preserving peace and restoring peace when defending against attack. It is not the problem of violence in defending peace that Augustine is primarily concerned with but the vices that are unleashed in the pursuit of war and the exercise of the right to inflict violence.

What is it about war that is to be blamed? Is it that those who will die someday are killed, so that those who will conquer might dominate in peace? This is the complaint of the timid, not the religious. The desire for harming, the cruelty of revenge, the restless and implacable mind, the savageness of revolting, the lust for dominating, and similar things these are what is justly blamed in wars. Often, so that such things might also be justly punished, certain wars that must be waged against violence of those resisting are commanded by God or some other legitimate ruler and are undertaken by the good. (Augustine 1994, pp. 221-222)

To this end, Augustine's primary audience is the soldiers tasked with acting under authority and seeking to reconcile in a practical way, in their own professional lives, the demands of being a Christian and being a soldier, as opposed to offering a more formal theory of the moral legitimacy of war in a Christian context. As Augustine takes the problem of war to be an unavoidable fact of a fallen or imperfect world, the focus is primarily on the jus in bello (justice in the conduct of war) obligations of individual soldiers and their conduct. As we can see in the passages above, the obligations are more generic virtues of Christian moral life applied to war as opposed to a specific set of norms or principles appropriate to the conduct of war. That said, one can infer from arguments about the appropriate attitude and motives of combatants ideas such as discrimination and non-combatant immunity that play such an important role in later just war thinking. Punishment must be directed at the perpetrators of violence or those 'resisting', and this is a clear indication that it can only be directed at fellow combatants and consequently that non-combatants are immune from punishment. Similarly, 'revenge, 'cruelty' and 'desire for harm' are also unjust motives. If they are allowed free rein, they must undermine the important issue of discrimination in the use of violence. Yet, Augustine is sufficiently realist not to demand (as Aquinas does) that the soldier must not will the death of an enemy in order to fight justly. Instead, Augustine argues that, once subdued, the enemy should be treated as a moral agent, who is after all also acting 'under authority', even if that authority has been misdirected.

When it comes to jus ad bellum (or the just cause for war), Augustine's argument is straightforward, given the basic fact overshadowing the discussion, namely the constant risk of attack from beyond the borders of the Empire or the challenge of marauding invaders such as the Goths and Vandals who interrupt peace. The right of war is a necessary tool of political authority to secure and maintain peace, either through self-defence when attacked or by 
pre-emptively attacking when faced with a significant threat of attack. What is not countenanced is the idea of war as a tool for destroying evil beyond the border, or against those who depart from the teaching of Christianity. Whichever way Augustine's arguments were deployed by later thinkers, no place was left for crusades against infidels or wars against heretics and schismatics. When violence is deployed against the terrorism of fanatical Donatists, Augustine regards this as what we would call a 'police action' and not a 'war on terror'. Only in the most egregious and specific cases can war be an appropriate response to the challenge of $\sin$.

As sin is everywhere in a fallen world, the existence of sin beyond borders would never be a legitimate cause for war, unless it was of such a kind as to threaten peace more generally, such as slaughtering those who are innocent and who can be protected. For example, Augustine's approach would permit intervention to prevent a Rwandan-style genocide because this is a general threat to peace, even if the perpetrators do not intend that it should spill beyond the country's borders. Similarly, Augustine leaves no place for preventive wars that pre-empt a neighbouring power becoming a threat in the future (Doyle 2011). Unlike modern just war theories, Augustine does not presuppose a progressive history that will evolve towards the overcoming of violence and conflict, or that a law of nature will reveal itself in the form of international law regulating and replacing war as a means of resolving disputes. Crucially for Augustine's view of politics, war is a consequence of sin and not merely of the absence of knowledge, or difficulties in coordinating human actions. Attempting to eradicate war, or acting to prevent the rise of threatening powers, would be another example of presuming to understand providence as God's plan for the fallen world. It is as dangerous to presume that war and its challenges do not form part of God's providence as it is to attribute war directly to the will of God. The trials of history and the divine plan that underpins them is ultimately mysterious and it is inappropriate for sinful men to usurp God's judgement in these matters.

As with all violence, the problem posed by war depends upon the purposes for which it is deployed and how those who undertake it act in its pursuit. It is these two dimensions that open up the distinction between jus ad bellum and jus in bello that plays an important role in subsequent Christian just war theory from Aquinas onwards. Augustine, nevertheless, sets the boundaries and identifies the challenges that remain central to Christian thinking about the role of violence and the conduct of war.

\section{Christianity, Augustinianism and international politics}

For many historians of thought, Augustine poses an acute problem in that he is not easily historicised - that is, reduced to a particular historical phenomenon that emerged in an historically contingent linguistic or socio-economic 
context. He is undoubtedly an historical figure with all the peculiarity and strangeness of his times, and we lose much if we ignore those elements of his thought. Yet (as we have seen above), he was a theologian who reflected on and shaped the Christian tradition. For Christians, this raises the challenge that, in so far as Augustine presented the truth in his teachings about the faith, he has an authority in the present. This is more than just making a claim to transcendental truth as many philosophers fall into that category and yet are not problematically historicised. But Augustine is different because his authority is tied up in a practice and tradition that continues into the present where he is taken to speak to readers as if they were contemporaries. Clearly, this is most obvious in the institutional Church, but I conclude this chapter by showing how his theological voice has been central to thinking about international relations in the 20th and 21 st centuries, especially with respect to the challenge of war, violence and just war, or with the challenge of history (Ratzinger 2018). This lasting legacy is illustrated in the discussion of Augustinian ideas in contemporary debates about the place of war in Christian ethics and politics, especially in the context of the War on Terror. It is also evident in the thought of the most significant neo-Augustinian thinker of mid-20th-century politics, Reinhold Niebuhr, whose Augustinian insights have contributed to the development of international relations and a qualified or Christian realist politics.

\section{War and the peaceable kingdom: Augustine and contemporary just war theory}

If there is any area where Christian theology and modern international political theory collide, it is the discussion of the war and its necessity or morality. This has been particularly true in the 20th and 21st centuries, which have seen not only unparalleled violence in two world wars, revolutions and their aftermaths but also moves to outlaw war and to subject conflict to regulation by international institutions charged with maintaining peace. Christian theologians have contributed to debates and campaigns for peace, but they have also returned to fundamental reconsiderations of the place of war in Christian practice and judgement. In 1930, at the high point of post-Great War idealism, the Lambeth Conference of the Anglican Communion passed a resolution that: 'This conference affirms that war as a method of settling international disputes is incompatible with the teaching and example of our Lord Jesus Christ' (Lambeth Conference 1930, resolution 25). The debate about the place of war and violence in Christian practice has been most recently challenged by a group of theologians such as the American theologian Stanley Hauerwas, who is a forceful proponent of Christian pacificism as a defining mark of Christian witness. His stance is despite his acknowledgement that the United States professes to be the most Christian of western democracies, whilst also having been at continuous war for the three decades from the end of the Cold War. Hauerwas 
recognises that Christian pacifism is demanding but remains uncompromising in its support, writing:

Are Christians not unjust if they allow another person to be injured or even killed if they might prevent that by the use of violence? Indeed, should not Christians call on the power of the state to employ its coercive force to secure more relative forms of justice? Such action would not be a question of using violence to be 'in control' but simply to prevent worse evil.

... the problem with attempts to commit the Christian to limited use of violence is that they too often distort the character of the alternatives. Violence used in the name of justice, or freedom, or equality is seldom simply a matter of justice - it is a matter of the power of some over others. Moreover, when violence is justified in principle as a necessary strategy for securing justice, it stills the imaginative search for nonviolent ways of resistance to injustice. For true justice never comes through violence, nor can it be based on violence. It can only be based on truth, which has no need to resort to violence to secure its own existence. (Hauerwas 2002 pp. 114-115)

As with Augustine, Hauerwas means by truth the risen Jesus Christ, not an idea or body of principles. But, just as with Augustine, Hauerwas's theological critics have been quick to challenge how quickly this position moves from the complex political judgement of life in a fallen (though ultimately redeemed) world to an injunction towards martyrdom, as the first response to the prevalence of evil amongst us as opposed to the last (O'Donovan 2003, pp. 9-10). This challenge to how a Christian should witness to their faith in the face of violence has become more acute, not less, as modern times have progressed. It has also highlighted the wisdom of Augustine as an important element of that theological and ethical debate. This can be seen particularly clearly in Nigel Biggar's provocatively titled book In Defence of War (2013). Biggar takes an unapologetically Augustinian position on the place of war within Christian political judgement. In a strikingly Augustinian move, he criticises Hauerwas for not addressing the relevant scriptural passages about the faith of the Roman soldier who is also 'under authority', the reference that Augustine mentions in Letter 189 to Boniface. For Biggar, it is striking that Hauerwas, as an evangelical Christian who gives special authority to the Bible, does not give greater weight to the reported words of Christ that do not insist on pacifism or rejection of the soldier's profession. Of course, one can respond that scripture needs to be interpreted in the round and not selectively. But, for evangelical Christians, it is not possible to just ignore reported speech. However, the echoes of Augustine are not simply confined to Biggar repeating this argument. The whole thrust of his book is concerned with showing how it remains possible (even in the 
industrial warfare of modern times) to adopt the appropriate Augustinian attitude to enemies and opponents, so that the individual soldier can avoid being consumed by the lust for violence.

Not all appeals to the authority of Augustine are quite so measured and nuanced. And, in light of the War on Terror and the associated Gulf Wars, it is not surprising that theologians and theologically informed political theorists should turn to Augustine and the classical thinkers of just war theory in search of practical guidance. Oliver O'Donovan's masterful short book Just War Revisited (2003) was published at the time of the second Gulf War but addresses issues raised by the first Gulf War in 1991. This involved an international coalition, dominated by the United States but also involving many countries, intervening militarily to enforce UN Resolutions that followed Iraq's invasion of Kuwait. O'Donovan's nuanced discussion ranges beyond simplistic accounts of the justice of war and includes discussion of such vexed but pressing matters as counter-insurgency war, the development of 'immoral weapons', and the place of war crimes trials or justice post-bellum. The arguments are problem-focused in an attempt to inform Christian judgement on unavoidable public and political issues, rather than as an exegetical strategy. But the shadow of Augustine looms large, not least because O'Donovan rejects the simplistic view of a tradition that is focused on the justice or moral rightness of war.

O'Donovan holds that 'just war theory' is neither a theory nor about the justice of war. Instead, it is an acknowledgement that an absence of peace brought on by a challenge to peace is a context for necessary action. As with Augustine, the re-establishment of peace involves the removal of that challenge to it: it is absolutely not a legalistic right or duty following from a natural or international law. Nor can war be reduced to the just punishment of an injustice within a legalistic moral order, contrary to the views of new just war theorists such as Fabre (2012) and McMahan (2009). Just as for Augustine, war is always an exception and a rupture of order: the practical challenge is to turn that exception to the re-establishment of order and peace. Consequently, war is not something about which there can be a final and complete theory. The ways in which peace is threatened are many. And so the theologically informed necessity of judgement about how to confront and respond to each new challenge must constantly be rethought.

A different type of book that emerged from the same political context was Jean Bethke Elshtain's Just War Against Terror (2003), a polemical response from the just war tradition to the critics of the War on Terror following 9/11. Elshtain is an Augustine scholar and eminent political theorist, but in this politically engaged book she shows impatience with those who argue that the United States should have stayed its hand and not declared the War on Terror. Augustine is appealed to directly, as an authority alongside Luther and the German anti-Nazi martyr Bonhoeffer, as Christian authorities for the recourse to the war when confronted with evil. 
[The] point is made most vividly by Luther, with his insistence that there is a 'time of the sword', but it has been widely, if not universally, shared in the historic Church. For Christians living in historic time and before the end of time, the pervasiveness of conflict must be faced. One may aspire to perfection, but living perfectly is not possible. To believe one is without sin is to commit the sin of pride and to become even more boastful in the conviction that a human being can sustain a perfectionist ethic. For St. Augustine, for Martin Luther, and for the anti-Nazi martyr Dietrich Bonhoeffer, the harsh demands of necessity as well as the command of love require that one may have to commit oneself to the use of force under certain limited conditions, and with certain intentions. (Elshtain 2003, p. 101)

Elshtain's argument goes beyond Augustine's writings on war and refers to the broader tradition of just war theory, which includes positions that he does not endorse. Her primary goal is not to explain Augustine's position but to show how the War on Terror can fall within traditional just war theory, given that the primary enemy when she wrote was Al-Qaeda, which is not a state or 'authority' of the relevant kind. In the justification of the war in Afghanistan she argues that, by giving succour and a home to Al-Qaeda, the Afghan state became a legitimate belligerent and target for attack. Similarly, Al-Qaeda breached the requirement to discriminate between combatants and non-combatants by targeting civilians, as in the attack on the Twin Towers.

Elshtain's book is deliberately polemical and intended to engage in public debate rather than the exegesis of Augustine's thought or more scholarly theological debates. But it also reinforces a strong Augustinian message in its account of the enemy of radical jihadi terrorism. She criticises the complacency of the U.S. and European 'liberal intelligentsia', who have forgotten the fundamental Augustinian insight about the nature of the fallen world in their assumption that the forces of law and consensual politics are reducing violence over time and eradicating the need to have recourse to war. This kind of progressivism is precisely the problem, because it cannot make space for evil and its ineradicability from the human condition. In this respect, she argues for the continuing relevance of Augustine's most fundamental teaching and one of Augustine's most important 20th-century followers, Niebuhr.

\section{Niebuhr: neo-Augustinianism and the challenge of history}

Reinhold Niebuhr (1892-1971) was an eminent American Protestant theologian and public intellectual during the middle years of the 20th century - a period that covered the Depression and World War II; the Cold War and the U.S. rise to global dominance; and subsequently the civil rights movement and the Vietnam War. He wrote many books, of which the most important for international 
political theory is Moral Man and Immoral Society (1932, reissued 2005). It was written during the collapse of the Wilsonian optimism following World War I and the rise of fascism, Nazism and Bolshevism in Europe. Like E.H. Carr in England, Niebuhr is considered a father of modern international relations as a consequence of his rejection of political and international idealism.

In response to the dark threats of the ideological currents of the mid-20th century, and the historical order in which they arose, Niebuhr resurrects a distinctively Augustinian vision of politics and history that continues to resonate now as Christian realism, manifested in three central positions. Firstly, liberalism and all forms of progressivism are a form of Pelagianism. Secondly, the usurpation of Christ by history must be rejected. Human redemption does not only happen within time and history is not a process that becomes the vehicle of that redemption. Finally, he rejects a naïve pacifism with its associated ideas that education and development will lead to the eradication of war and conflict.

Niebuhr does not write as an historian of thought, or as an academic theologian expounding and explaining Augustine's thought to a modern age. So the question confronting such theologians, about how accurate his depiction of Augustinian realism is, remains tangential. That said, Moral Man and Immoral Society does offer a sympathetic interpretation of Augustine's position in Chapter 3. What is most striking is the way in which the challenges that Augustine faced in City of God reappear in modern politics, particularly the ineradicability of sin and the prevalence of Pelagian overreach in the progressive political movement of early 20th-century American politics and in the social gospel of liberal Protestantism, as he saw it.

For Niebuhr, the chief failing of liberal Protestantism was its accommodation to post-Enlightenment thought and its abandonment of elements of orthodox Christian teaching about sin and redemption, instead invoking ideas of secular rationalism linked with Christian piety. A focus on loving one's neighbour and care for the poor connected the liberal Protestant social gospel of Rauschenbusch and Gladden with the secular progressive liberalism of pragmatists such as Dewey. Central to this view is the secularisation of $\sin$, which becomes a psychological or sociological category, and the claim that human error is the basis for social and interpersonal conflict and that this is exacerbated by social conditions and personal circumstances. For the advocates of the social gospel, knowledge of the New Testament teaching of Jesus would educate people in how to lead a good life. But, as the substance of that teaching is taken to be consistent with reason or good sense, it converges with the secular morality of progressive liberalism in its focus on individual educational and social improvement and the eradication of the social conditions of vice through public education, poverty reduction and temperance reform (prohibition of alcohol). With progressive legislation and social reform, the conditions of sin and conflict can be eradicated, and social and political harmony can be created. As with the Pelagians in Augustine's time, the exercise of individual will and moral 
action are seen here as leading to overcoming sin and error. Niebuhr offers a forceful rejection of this naïve optimism:

What is lacking among all these moralists, whether religious or rational, is an understanding of the brutal character of the behaviour of all human collectives, and the power of all self-interest and collective egoism in all intergroup relations. Failure to recognise the stubborn resistance of group egoism to all inclusive social objectives involves them [the moralists] in unrealistic and confused political thought. (Niebuhr 2005: xvi)

His point here does not depend upon the Christian doctrine of original sin, although Niebuhr does subscribe to that doctrine. Rather, here he argues that human experience supports the idea that the human inability to coordinate social action and to overcome partial interests has the same effect as orthodox Christian teaching about sin. Whatever their sources, the limitations of human nature undermine political faith in inevitable progress towards human emancipation and social well-being. Conflict cannot be designed out of human experience by institutional reform and psychological manipulation, whether that be through welfare states in the domestic context or through Leagues of Nations in the international context. Niebuhr endorses the Augustinian vision as a more realistic account of modern society and politics from which contemporary religion and political philosophy can still learn:

Augustine concludes that the city of this world is 'compact of injustice' that its ruler is the devil, that it is built by Cain and that its peace is secured by strife. That is a very realistic interpretation of the realities of social life. It would stand in wholesome contrast to the sentimentalities and superficial analyses, current in modern religion. (Niebuhr 2005, p. 46)

Believing in the self-sufficiency of human nature and progress towards human redemption reruns Pelagian heresy in its overconfidence. Niebuhr takes the argument further in challenging historicist political ideologies as dangerous attempts to replace Christ as the source of human redemption. Niebuhr sees the challenge of ideological politics in the 1930s as a reflection of this Christian heresy and in Moral Man and Immoral Society seeks to extend that warning into a critique of contemporary political ideology. The fundamental issue at the heart of Augustine's lesson for modern politics is the warning against seeking salvation in and through human history. For progressive liberals, this manifests itself in the faith that historical progress will lead to the steady eradication of conflict and disorder.

But it is not only progressive liberals who offer this faith. It reaches its most stark restatement in the revolutionary politics of Bolshevism, the most recent 
example of redemptive politics when Niebuhr wrote. The legacy of the 1917 Russian Revolution for European politics, and to some extent for U.S. politics in the depths of the 1930s' depression, provided an unsettling account of redemption in human history, and included that claim that the Marxist materialist dialectic of class conflict in history is the story of human redemption. In this view, the working-out of class revolution will involve the overcoming of all conflict and contradictions through the final class conflict. Here history in this dialectical process usurps the position of Christ as redeemer, with all the dangers this poses to human life by liberating and justifying millennial eschatological violence. The dangers of such false redeemers - or 'Antichrists', to use apocalyptic language - is that they unleash violence and disorder, promising a final overcoming of disorder but without being able to deliver that, and instead creating further violence and destruction. There can be no historical event that redeems the destruction of human lives on the promise of building a better society or a utopia on earth. Such things are always false gods and they need to be recognised as such.

Two conclusions follow from Niebuhr's analysis of ideological political movements in terms of Augustinian theological categories. Either they are genuinely heretical and usurp the place of Christian redemption or, for those who are uncomfortable with the Christian theological perspective, they offer a false optimism about the historical process that can ultimately never be vindicated. Christians and political sceptics alike can therefore converge on a rejection of the political naivety of utopianism, as the danger of creating false gods. In this respect, Niebuhr initiates an anti-perfectionist politics that was to attract many to a sceptical liberalism in the post-1945 period as part of a turn against ideology and ideological politics. There was also rejection of historicism or historical theodicies by thinkers as diverse as Popper, Oakeshott and Berlin. For all of these philosophers, just as for Augustine a millennium and half before them, either history is impenetrable in its logic and meaning or it has no such single or meta-narrative structure: it cannot contain the clue to human emancipation and the overcoming of conflict.

That said, Niebuhr does not retreat in despair or reject the value of political action. Instead, he develops a different perspective on liberal politics that conceives of the constitutional order as a contingent realm in which fundamental disagreements about moral or religious questions can be disciplined, without asserting a political authority to regulate on their truth. Politics becomes a domain of compromise on fundamental questions, a place where temporary or meliorist solutions can be provided for social and economic challenges. Meliorism, or the idea that liberal politics is about fixing or mitigating problems, and not resolving grand issues such as human redemption, became central to the post-war European liberal politics of Popper or Rawls - despite Rawls's antiAugustinian claim that ' $[j]$ ustice is the first virtue of social institutions'. In many respects, this late political liberalism reflects Augustine's own attitude towards 
politics and the tools of politics, including the deployment of violence and coercion. Whilst Augustine saw political action as an inescapable evil given our fallen natures, he nevertheless also saw politics as necessary and unavoidable.

This Augustinian vision of politics as a response to man's fallen nature is most visible in Niebuhr's rejection of idealism after the 1914-1918 war, and its attempt to regulate and abolish war through the League of Nations. Niebuhr is at his most sceptical on this naïve optimism. He writes:

This glorification of the League of Nations as a symbol of a new epoch in international relations has been very general, and frequently very unqualified, in the Christian churches, where liberal Christianity has given itself to the illusion that all social relations are being brought progressively under 'the law of Christ'. (Niebuhr 2005: xvii)

Niebuhr does not celebrate war and he shares the Augustinian sense of war as tragic. But equally he thinks that the regulation of international affairs is not straightforward: one cannot simply will the replacement of war with law, as the enthusiasts for the League seemed to believe. The problem of the League and of all such attempts to constitutionalise international politics is that they assume away precisely the partiality and interest-driven character of national politics, so that high-minded idealism is always undermined by the clash of interests between respective ruling classes. Whilst the internal politics of states remains so fraught with class and racial conflict, it is no wonder that international politics should be equally consumed by the passions of national self-assertion and the struggles for recognition that follow from it. The arguments of Moral Man and Immoral Society tend towards either a realistic pacifism or qualified support for war as a last resort to defend justice, and they give a profound warning against wars of ideology, such as the 'Christian west' against 'godless Bolshevism'. However, by the time of World War II Niebuhr had become more realist and he supported the war effort as a necessary response to egregious injustice and evil. Similarly, during the Cold War, Niebuhr advocated confrontation with the USSR as a further false god trying to impose its will as the salvation of humanity. His stance made him a central inspiration for the development of the modern discipline of international relations in American political science departments, alongside the former diplomat George F. Kennan and émigré thinkers such as Hans Morgenthau. Yet, Niebuhr was no naïve realist or Cold War warrior. He remained sceptical about the claims of politics, especially during the civil rights struggles of the 1960s and the Vietnam War. Like Kennan and Morgenthau, he opposed this intervention as an unnecessary war of choice based on a false perspective. It was precisely the dangerous form of ideological confrontation between 'western civilisation and godless communism' that he counselled against. Once again, his stance echoes that of Augustine in recognising the politics of imperfection. The danger facing the United States was that of its already strong political exceptionalism becoming a new form of 
Constantinianism - a belief that the USA was an empire endorsed and sanctioned by God as his means of redeeming mankind.

This 'middle position' between a sceptical realism and liberal idealism is similar to the 'society of states' view of Wight and Bull in the English School, which itself reflects the similar Christian Augustinianism of Martin Wight and Hubert Butterfield. They reject the hard realism of a Hobbesian view of international politics on the grounds that state sovereignty is an artificial and historically contingent political form. They also reject the idealist view that history is tending towards either a liberal empire backed by American power or, under the guise of globalisation, a world state. Niebuhr is not alone in restating the Augustinian warning against 'Constantinianism' in modern politics, but he is important in reminding modern states that when they confront great evils (such as Nazism and Stalinist Bolshevism) they should not forget their own similar tendency to claim to be a solution to the problem of history. Although Augustine's world is far removed from that contemporary politics and international relations, in one respect at least, his rejection of the 'end of history', he could not be more contemporary.

\section{Bibliography}

\section{Essential reading}

Augustine. (1994). Political Writings, trans. M.W. Tkacz and D. Kries, intro. E.L. Fortin. USA: Hackett.

Augustine. (1998). The City of God Against the Pagans, ed. R.W. Dyson. UK: Cambridge University Press.

\section{Secondary reading}

Biggar, Nigel. (2013). In Defence of War. UK: Oxford University Press.

Butterfield, Herbert. (1962). Christianity, Diplomacy and War. UK: Wyvern Books.

Connolly, William, E. (1993). The Augustinian Imperative: the Politics of Morality. USA: Sage.

Doyle, Michael W. (2011). Striking First. USA: Princeton University Press.

Elshtain, Jean Bethke. (1995). Augustine and the Limits of Politics. USA: University of Notre Dame Press.

Elshtain, Jean Bethke. (2003). Just War against Terror. USA: Basic Books.

Fabre, Cécile. (2012). Cosmopolitan War. UK: Oxford University Press.

Hauerwas, Stanley. (2002). The Peaceable Kingdom: A Primer in Christian Ethics. USA: Notre Dame University Press.

Hauerwas, Stanley. (2011). War and the American Difference: Theological Reflections on Violence and National Identity. USA: Baker Academic. 
Markus, Richard A. (1983). 'Saint Augustine's Views on the "Just War", in W.J. Sheils (ed.) The Church and War: Church History, vol. 20. UK: Oxford University Press, pp. 1-13.

Markus, Richard A. (1988). 'The Latin Fathers', in James Henderson Burns (ed.) The Cambridge History of Medieval Political Thought c. 350-1450. UK: Cambridge University Press, pp. 92-122.

McMahan, Jeff. (2009). Killing in War. UK: Clarendon Press.

Niebuhr, Reinhold. [1932] (2005). Moral Man and Immoral Society. USA: Continuum.

O'Donovan, Oliver. (1996). The Desire of the Nations: Rediscovering the Roots of Political Theology. UK: Cambridge University Press.

O'Donovan, Oliver. (2003). The Just War Revisited. UK: Cambridge University Press.

O’Donovan, Oliver. (2005). Ways of Judgement. UK: W. Eerdmans.

O'Donovan, Oliver; and Lockwood O'Donovan, Joan. (2004). Bonds of Imperfection: Christian Politics Past and Present. USA: W. Eerdmans.

Ratzinger, Joseph. [Pope Benedict XVI] (2008). Church, Ecumenism and Politics: New Endeavours in Ecclesiology. USA: Ignatius Press.

Ratzinger, Joseph. [Pope Benedict XVI] (2018). Faith and Politics. USA: Ignatius Press.

Song, Robert. (1997). Christianity and Liberal Society. UK: Clarendon Press. Williams, Rowan. (2016). On Augustine. UK: Bloomsbury.

\section{Suggestion for finding open access versions of St Augustine's texts}

Perseus Digital Library, Tufts University

https://www.perseus.tufts.edu/hopper/searchresults?q=St+Augustine 